\title{
MOEHRINGIA PENTANDRA \\ J. GAY (CARYOPHYLLACEAE), NEW TO THE FLORA OF CROATIA
}

\section{Fabrizio Martini ${ }^{1}$ \& Claudio Peruzovich ${ }^{2}$}

${ }^{1}$ V. F. Fortunio 10, Trieste, Italy (e-mail: fbrz.mrtn@gmail.com)

${ }^{2}$ V. Udine 133, Martignacco (UD), Italy (e-mail: peruzo2@virgilio.it)

Martini, F. \& Peruzovich, C.: Moehringia pentandra J. Gay (Caryophyllaceae), new to the flora of Croatia. Nat. Croat. Vol. 28, No. 1., 155-160, Zagreb, 2019.

We describe and discuss the discovery of Moehringia pentandra from the Osorščica massif on the island of Lošinj. The species, new to the Croatian flora, grows on a calcareous substrate within an artificial Pinus nigra forest along with some small holm oaks (Quercus ilex). The herbaceous layer is characterized by vernal thermophilous therophytes, mainly with euri- or steno-Mediterranean distribution. We also underline the difficulty of distinguishing in the field M. pentandra from Stellaria pallida, whose main diacritical features are also analyzed. A key to the genus Moehringia in Croatia is proposed.

Keywords: Moehringia pentandra, Lošinj Island, ecology, phytocoenology, morphology

Martini, F. \& Peruzovich, C.: Moehringia pentandra J. Gay (Caryophyllaceae), nova vrsta za hrvatsku floru. Nat. Croat. Vol. 28, No. 1., 155-160, Zagreb, 2019.

U radu se opisuje i razmatra pronalazak vrste Moehringia pentandra na masivu Osorščice na otoku Lošinju. Ova nova vrsta za hrvatsku floru raste na vapnenačkoj podlozi u posađenoj šumi bora Pinus nigra i nešto manjih hrastova crnika (Quercus ilex). Sloj zeleni karakteriziraju proljetni termofilni terofiti, većinom euri- ili steno-Mediteranske raprostranjenosti. Naglašavaju se poteškoće u terenskom razlikovanju M. pentandra od vrste Stellaria pallida i analiziraju glavne razlikovne osobine. Predlaže se ključ za rod Moehringia u Hrvatskoj.

Ključne riječi: Moehringia pentandra, otok Lošinj, ekologija, fitocenologija, morfologija

\section{INTRODUCTION}

Moehringia pentandra J.Gay (Caryophyllaceae) grows mainly around the centralwestern Mediterranean Basin (Monserrat Martí, 1990). Its European distribution includes the Iberian Peninsula (Spain, Portugal and the Balearic Islands), Southern France, Corsica, Peninsular Italy, Sicily and Sardinia up to North-eastern Greece (Jalas \& Suominen, 1983). On the African side, the species can be found in Morocco, Algeria and Tunisia, while it does not occur in the Canary Islands (Marhold, 2011). The attribution of Halliday (1964) for the former Yugoslavia was subsequently refuted by Jalas \& SuOMinen (1983) and Hind (1996). In Croatia, the species does not appear in the study by Volarić-Mršrć (1978) and LOVAŠEN-EBERHARD (1994) or in the most recent checklist by NiKolić (2019) or in the Flora of Istria by RotTENSTEINER (2014).

Following NiкоLIć (2019), the genus Moehringia in Croatia is represented by 6 species: M. bavarica, M. ciliata , M. muscosa, M. pentandra, M. tommasinii and M. trinervia. 


\section{MATERIALS AND METHODS}

Morphological and morphometric analysis was performed both on fresh material and on herbarium specimens deposited in CNHM, MFU and TSB (acronyms follow Index Herbariorum, 2017) and in the private collection of F. Martini. A Leica EZ4 HD microscope was used for morphometrical observations and for taking photographs. The scientific nomenclature follows NiкоLIć (2019).

\section{RESULTS AND DISCUSSION}

Moehringia pentandra J.Gay, Ann. Sci. Nat. (Paris), sér. 1, 26 : 230 (1832).

Synonyms: Arenaria pentandra (J.Gay) Ardoino [1867, Fl. Anal. Alpes Marit., 67], non Dufour [1821]; A. Trinervia subsp. Pentandra (J.Gay) Bonnier [1913, Fl. Compl. Fr., 2 : 55]; Moehringia thasia Stoj. \& Kitan. [1945, Ann. Univ. Sofia Fac. Phys. Math., ser. Sci. Nat., 41 : 293]

Moehringia trinervia subsp. Pentandra (J.Gay) Nyman [1878, Consp. Fl. Eur., 112].

\section{Specimina collecta.}

Hrvatska: Otok Lošinj (Croatia: Lošinj Island), Osorščica southeastern side,

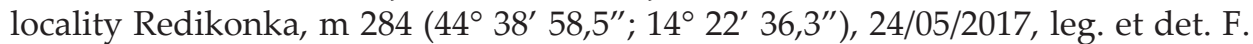
Martini \& C. Peruzovich, CNHM (Inv. nbr. 600:ZAG; 8312:BOB) and MFU.

The species (Fig. 1) was first observed in May 2017 by the Floristic Group of Friuli Venezia Giulia (Udine, Italy), during an excursion on the mount of Osor (Osorščica), southwest of the village of Nerezine, on Lošinj Island (Fig. 2). A further excursion was carried out in June 2018 to make some morphological floristic and environmental observations as follows.

The detection area is located along the path that goes from Nerezine up towards the southeastern ridge of the Osorščica massif, within an artificial Pinus nigra

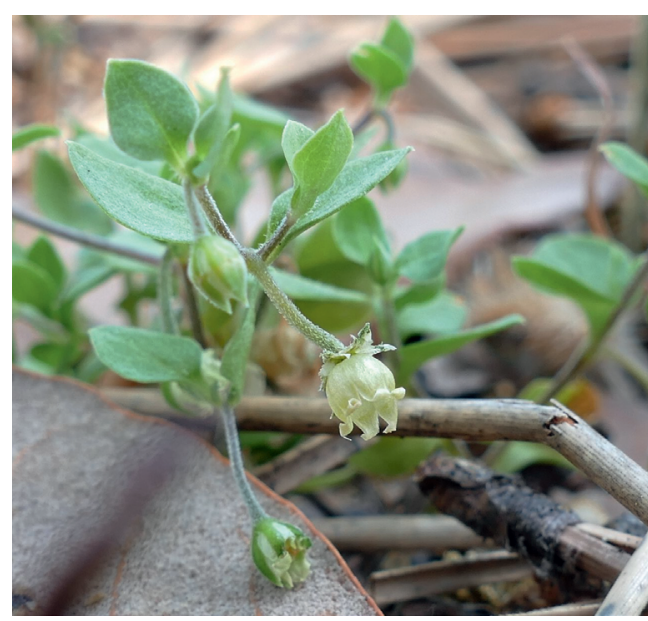
forest along with some small holm oaks (Quercus ilex) on a calcareous substrate partly covered with pine needles (Fig. 3). The shrubbery (cover $5 \%$ ) is reduced to sporadic specimens of Juniperus oxycedrus and Phillyrea latifolia. Such a type of wood locally forms a strip of vegetation above the holm oak Mediterranean forest, which the aforementioned wood species of the relevé - excluding Pinus nigra - come from. The grass layer (cover

Fig. 1. Inflorescence of Moehringia pentandra. 


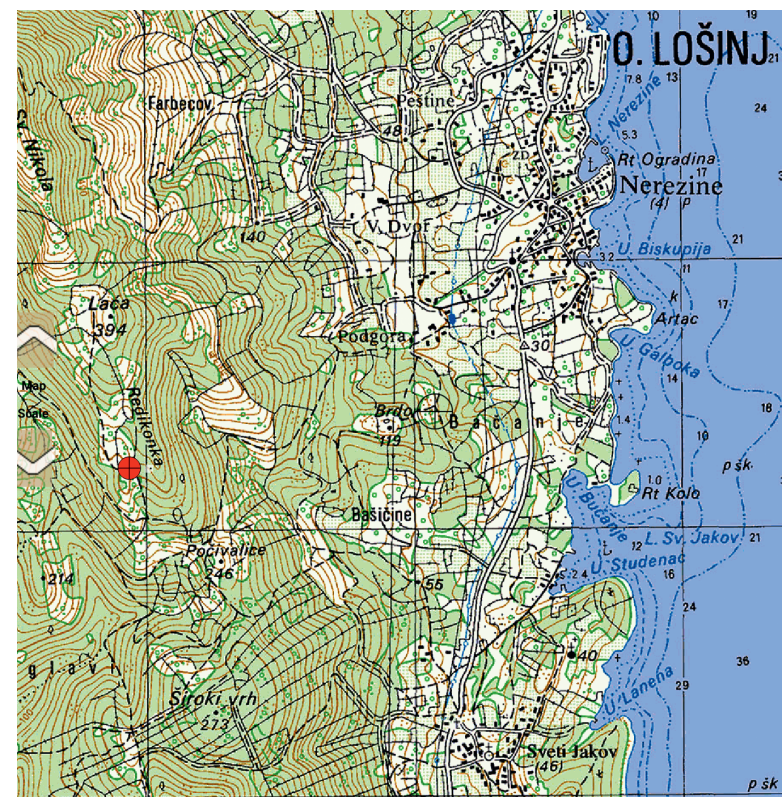

Fig. 2. Geographic position of Moehringia pentandra population on the Osorščica massif (Lošinj Island).
$20 \%$ presents the following species: Moehringia pentandra, Arenaria Brachypodium distachyon, Bromus madritensis, Capsella rubella, Cerastium pumilum subsp. glutinosum, Cynosurus echinatus, Desmazeria rigida, Galium murale, Gastridium ventricosum, Geranium purpureum, Helichrysum italicum subsp. italicum, Leontodon crispus subsp. crispus, Melica ciliata subsp. ciliata, Medicago lupulina, Myosotis arvensis, Reichardia picroides, Stellaria pallida, Torilis arvensis subsp. purpurea, Valantia muralis, Veronica arvensis, Vulpia ciliata.

The population of M. pentandra consists of scattered specimens of reduced size, $3-8 \mathrm{~cm}$ tall, generally with procumbent or creeping stems. Outside this area the presence of the species continues on the side of the path for about fifty meters, although strongly thinned out. The herbaceous layer, sparse and very discontinuous, is characterized by vernal thermophilous therophytes, mainly with euri- or steno-mediterranean distribution, such as Bromus madritensis, Brachypodium distachyon, Capsella rubella, Galium murale, Valantia muralis, Vulpia ciliata and others.

It seems interesting that, at least within the detected phytocoenosis, $M$. pentandra shares a habitat with Stellaria pallida, whose distinction from the first one is far from easy in the field because of their strong similarity, especially in the vegetative habitus (see also Tison \& De Foucault, 2014). The flowers, tiny and inconspicuous due to the reduction or complete absence of petals, have 5 (8) stamens in M. pentandra, 1-3 (5) in S. pallida. The same is true for the other main vegetative features, summarized in Tab.1 (from Monserrat Martí, 1990; Romo, 1990; Hind, 1996; Minuto \& Casazza, 2018).

The specimens of Osorščica, examined on site and subsequently dried, show stems and branches with two opposing lines of hairs on the underside and with a diffused hairiness on the upper part; most leaves have a hairless or a ciliate edge in the proximal part, but we also observed the presence of cilia along the entire length or solely in the distal part of the edge; petals are absent or sometimes rudimentary; 5 stamens (sometimes with another 1-2 rudimentary ones); seed length is about $0,6-0,8 \mathrm{~mm}(0,72 \mathrm{~mm}$ average), with very small and \pm lobed strophiole (Fig. 4). 
Tab. 1. Main distinctive characters (reproductive and vegetative) between Moehringia pentandra and Stellaria pallida.

\begin{tabular}{|l|l|l|}
\hline Characters & Moehringia pentandra & Stellaria pallida \\
\hline Petals & rudimentary or absent & absent (rarely minute) \\
\hline Number of stamens & $5(8)$ & $1-3$ (very rarely 5) \\
\hline Seeds length & $0,6-0,8 \mathrm{~mm}$ & $1-1,2 \mathrm{~mm}$ \\
\hline Seed strophiole & small, branched & absent \\
\hline Stem indumentum & $\begin{array}{l}2 \text { distinct lines of hairs at least } \\
\text { at base, hairy all around above }\end{array}$ & $\begin{array}{l}1(2) \text { line of hairs below each } \\
\text { internode }\end{array}$ \\
\hline Leaf edge & ciliate almost at base & glabrous \\
\hline
\end{tabular}

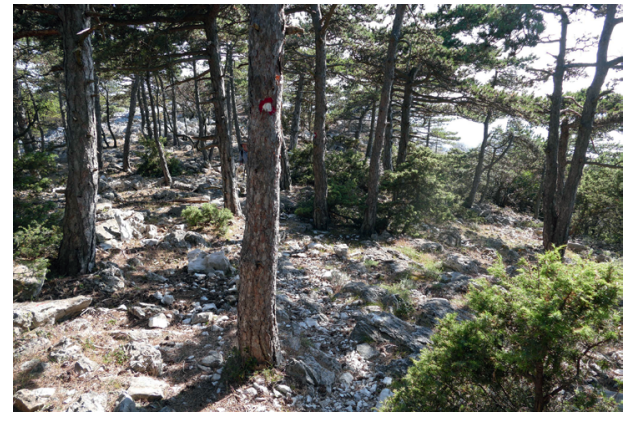

Fig. 3. Habitat of Moehringia pentandra (photo by C. Peruzovich).

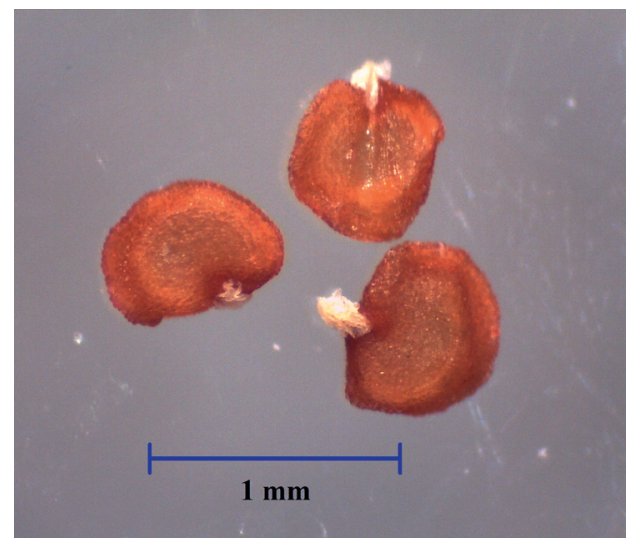

Fig. 4. Seeds with strophiole of Moehringia pentandra from the Osorščica massif (original photo by F. Martini).

\section{CONCLUSIONS}

Habitat and the plant association observed on Osorščica could suggest an accidental introduction of Moehringia pentandra linked to the planting of the black pine. On the other hand, similar environments are not uncommon, either on the Dalmatian islands or in the hinterland, so that it is possible that even elsewhere in Croatia M. pentandra has so far escaped observation or been mistaken for Stellaria pallida.

The potential finding of $M$. pentandra along the eastern Adriatic side would extend the eastern part of the Mediterranean distribution (Greece) to the north and, in such a case, the Osoršcica station would represent a connection between the Italian peninsula and the Illyrian-Balkan region.

In the light of the recent finding, we think it is useful to propose a key to the genus Moehringia in Croatia: 
1 Petals rudimentary (0,5-1,2 mm long) or absent; stamens 5 (rarely 8).

Petals developed (3,5-7 mm long); stamens 8-10

2 Sepals and petals 4 . Stamens 8 (very rarely 5-6); styles usually 2; capsule dehiscing with 4 teeth 3

Sepals and petals 5. Stamens 10; styles usually 3; capsule dehiscing with 6 teeth

3 Plant green; stems thin (0,5-0,7 mm in diam.); leaves needle-shaped sometimes shiny when fresh, rarely glaucescent

M. muscosa

Plant greyish-green; stems thicker (0,6-1,1 mm in diam.); leaves semi-terete, the upper linear or elongate-spathulate, glaucous, not shiny when fresh.

M. tommasinii

4 Leaves ovate, 3-5 veined; sepals with ciliate margin. M. trinervia

At least the upper leaves linear; sepals glabrous .5

5 Leaves ciliate at base, green; pedicels 5-8 (10) $\mathrm{mm}$. M. ciliata

Leaves glabrous, glaucous; pedicels 10-25 mm M. bavarica

\section{ACKNOWLEDGEMENTS}

The authors are grateful to Dr. S. Buzjak (Croatian Natural History Museum) for advice and editorial assistance, Dr. G. Juresich for the revision of the English text and the anonymous reviewers for their comments on the first version of the paper.

Received January 23, 2019

\section{REFERENCES}

Halliday, G., 1964: Moehringia L. In: Tutin, T.G., Heywood, V.H., Burges, N.A., Valentine, D.H., Walters, S.M. \& D.A. Webb (Eds.), Flora Europaea. 1. Lycopodiaceae to Platanaceae. Cambridge: University Press. p.123-125.

Hind, D.J.N., 1996: Moehringia L. In: Tutin, T.G., Burges, N.A., Chater, A.O., Edmondson, J.R., Heywood ,V.H., Moore, D.M., Valentine, D.H., Walters, S.M. \& D.A. Webb (Eds.), Flora Europaea. 1. Psilotaceae to Platanaceae. Cambridge: University Press. p. 148-152.

INDEX HERBARIORUM, 2017: Index herbariorum, a global directory of public herbaria and associated staff. New York Botanical Garden's Virtual Herbarium. [http://sweetgum.nybg.org/science/ih].

Jalas, J. \& J. Suominen (Eds.), 1983: Atlas Florae Europaeae. 6. Caryophyllaceae (Alsinoideae and Paronychioideae). Helsinki: Helsingin Liikekirjapaino Oy.

Lovašen-Eberhard, Ž.,1994: Moehringia L. In: Nikolić T. (Ed.), Flora Croatica. Index Florae Croaticae, Pars 1. Nat. Croat. 3, suppl. 2, 73.

Marhold, K., 2011: Caryophyllaceae. In: Euro+Med Plantbase - The information resource for EuroMediterranean plant diversity. Moehringia pentandra J. Gay. Accessed through: Euro+Med PlantBase at http://ww2.bgbm.org/euroPlusMed/PTaxonDetail.asp?UUID=BD38F89A-63D2-4050- 
BFA2-7E36A0FB92F0

Minuto, L. \& G. Casazza, 2018: Moehringia L. In: Pignatti, S., Flora d'Italia. 2, 92-98. Milano, Bologna: Edagricole.

Monserrat Martí, J.M., 1990: Moehringia L. In: Castroviejo, S., Lainz, M., López Gonzaléz, G. et al., Flora Iberica. II. Platanaceae-Plumbaginaceae (partim). 2. Madrid: Real Jardín Botánico, CSIC. p. 225-230.

Niкоцić, T. (Ed.), 2019: Flora Croatica Database. University of Zagreb, Faculty of Science, Department of Botany. https://hirc.botanic.hr/fcd/

Romo, A.M., 1990: Stellaria L. In: Castroviejo, S., Lainz, M., López Gonzaléz, G. et al., Flora Iberica. II. Platanaceae-Plumbaginaceae (partim). 2. Madrid: Real Jardín Botánico, CSIC. p. 253-260

RotTEnsteinER, W.K., 2014. Exkursionsflora für Istrien. Klagenfurt: Verlag des Naturwissenschaftlichen Vereins für Kärnten.

Tison, J.-M. \& B. De Foucault (coords.), 2014: Flora Gallica. Flore de France. Méze: Biotope.

Volarić-Mršić, I., 1978: Rod Moehringia L. In: TrinajSTIĆ I., Analitička Flora Jugoslavije 1 (4), 519-526. Institut za Botaniku Sveučilišta u Zagrebu, Zagreb: Grafički zavod Hrvatske. 